\title{
First record of the leptonectid ichthyosaur Eurhinosaurus longirostris from the Early Jurassic of Switzerland and its stratigraphic framework
}

\author{
Achim G. Reisdorf • Michael W. Maisch • \\ Andreas Wetzel
}

Received: 10 May 2010/Accepted: 10 July 2011/Published online: 20 September 2011

(C) Swiss Geological Society 2011

\begin{abstract}
An incomplete skull of the leptonectid ichthyosaur Eurhinosaurus longirostris found in the Rietheim Member (previously "Posidonienschiefer"; Toarcian, Early Jurassic) of Staffelegg, Canton Aargau, is the first record from Switzerland of this taxon and supports the status of Eurhinosaurus longirostris as a palaeobiogeographic very widespread ichthyosaur species in the Early Toarcian of Western Europe. Being from either the Bifrons or Variabilis zone, it is one of the youngest records of Eurhinosaurus and one of the few diagnostic ichthyosaur finds from this time interval. The partial skull is well articulated and preserved three-dimensionally in a carbonate concretion. Both the mode of preservation of the ichthyosaur and an associated ammonoid (Catacoeloceras raquinianum) provided the age of the concretion, which had been collected from scree. Taphocoenosis and taphonomy show the $C$. raquinianum to be one of few non re-worked fossils recorded from the Early to Late Toarcian boundary (Bifrons/Variabilis zone) of northern Switzerland in general and of this ammonite species in particular. The Toarcian section at Staffelegg differs from other localities where strata of the same age are exposed with respect to facies variations of the Rietheim Member (previously
\end{abstract}

Editorial handling: Daniel Marty.

A. G. Reisdorf $(\bowtie) \cdot$ A. Wetzel

Geologisch-Paläontologisches Institut, Universität Basel,

Bernoullistrasse 32, 4056 Basel, Switzerland

e-mail: achim.reisdorf@unibas.ch

M. W. Maisch

Staatliches Museum für Naturkunde Stuttgart,

Rosenstein 1, 70191 Stuttgart, Germany
"Posidonienschiefer", Early Toarcian) and the extraordinarily high thickness of the Gross Wolf Member (previously "Jurensis-Mergel”, Late Toarcian).

Keywords Ichthyosauridae - Lias · Toarcian · Staffelegg Formation · Catacoeloceras raquinianum

Zusammenfassung Von der Staffelegg (Kanton Aargau, N-Schweiz) wird ein unvollständiger Schädel, des leptonectiden Ichthyosauriers Eurhinosaurus longirostris aus dem Rietheim-Member (bisher "Posidonienschiefer", Toarcium, Früh-Jura) beschrieben. Das Fossil repräsentiert den ersten Nachweis dieses weitverbreiteten Taxons aus der Schweiz und ist auch aufgrund seines stratigraphischen Alters interessant. Da es aus dem Grenzbereich Bifrons-/ Variabilis-Zone stammt, stellt es einen der jüngsten Nachweise von Eurhinosaurus und einen der wenigen diagnostischen Ichthyosaurierfunde aus diesem Zeitintervall überhaupt dar. Eingebettet in einer Kalkkonkretion weisen die Schädelreste eine dreidimensionale Erhaltung und einen hohen Artikulationsgrad auf. Sowohl der Erhaltungszustand der Ichthyosaurierreste als auch ein mit ihnen assoziiertes Catacoeloceras raquinianum bilden die Datierungsgrundlage dieser im Hangschutt aufgefundenen Kalkkonkretion: Taphozönose und Taphonomie weisen den Ammoniten als einen der wenigen nicht aufgearbeiteten faunistischen Belege aus dem Grenzbereich Früh-/Spät-Toarcium (Bifrons-/ Variabilis-Zone) der N-Schweiz im allgemeinen und der Art C. raquinianum im Speziellen aus. Das Toarcium-Profil der Staffelegg weicht in vielerlei Hinsicht von den gleichaltrigen Vorkommen der N-Schweiz ab. Besonders bemerkenswert sind hierbei die Faziesvariationen des Rietheim Members (bislang "Posidonienschiefer", Früh-Toarcium) und die 
aussergewöhnlich grosse Mächtigkeit des Gross Wolf Members (bislang “Jurensis-Mergel”, Spät-Toarcium).

\section{Introduction}

Switzerland is one of the few countries from which ichthyosaur remains of Triassic to Cretaceous age are known (Maisch et al., 2008). Identifiable ichthyosaur specimens of post-Triassic age, however, are exceedingly rare in Switzerland. Except for unpublished ichthyosaur remains from the Late Kimmeridgian of Ruppoldingen (south of Olten, Canton Solothurn), all Swiss Jurassic ichthyosaur specimens are of Early Jurassic age (Maisch et al., 2008, fig. 1). Six specimens are documented so far, four of which are from Toarcian strata: (1) a nearly complete skeleton of Stenopterygius sp. from the Falcifer zone of Teysachaux (Canton Fribourg; e.g., von Huene, 1939; Furrer, 1958; Maisch, 2008); (2) a complete skull from the Falcifer zone of Asuel (Canton Jura; B. Hostettler pers. comm. 2007); (3) an incomplete skull from the Early to Late Toarcian boundary of Staffelegg (Canton Aargau; this paper); (4) an incomplete skull of unknown stratigraphic position from the same locality (Maisch \& Reisdorf, 2006a, b).

Like these rather complete specimens, most disarticulated ichthyosaur remains, including isolated bones and teeth of post-Triassic age from northern Switzerland, derive from the bituminous mudstones and limestones of the Early Toarcian (Maisch \& Reisdorf, 2006a, b). In southern Germany, the Belgium/Luxemburg localities and France, the same stratigraphic interval yielded the most abundant ichthyosaur remains, contributing significantly to the fame of the central European fossillagerstätten of this age (e.g., von Buch, 1839: 42; Martill, 1993; Floquet et al., 2003; Fischer et al., 2009, 2011).

This study focusses on the ichthyosaur found at Staffelegg ( 3 above) from the Early to Late Toarcian boundary and its host sediment. This discovery is of significance for the following reasons: (1) The skull can be assigned to Eurhinosaurus and thus represents the first record of this genus from Switzerland. (2) Over 100 years after the discovery of the skeleton of Stenopterygius near Teysachaux, this Eurhinosaurus specimen represent only the second determinable record of ichthyosaurs from the Early Jurassic age from Switzerland. In contrast to the specimen from Teysachaux whose authenticity was discussed by Furrer (1958) and Menkveld-Gfeller (1998), the original arrangement of skeletal remains was not altered in the course of preparation and is here considered as entirely unchanged. (3) This Eurhinosaurus is stratigraphically slightly younger than the majority of the central European leptonectid ichthyosaurs from the Early Toarcian (e.g., Benton \& Taylor, 1984; Pharisat et al., 1993; Floquet et al., 2003). (4) The new occurrence demonstrates the wide palaeobiogeographic distribution of Eurhinosaurus longirostris, as compared to many other Toarcian marine reptiles, including most ichthyosaurs. E. longirostris is, along with Stenopterygius triscissus and Hauffiopteryx typicus (see Maisch, 2008) one of the few species of Early Toarcian marine reptiles that has so far been definitely recorded from all Western European areas with substantial Toarcian marine reptile faunas. (5) Catacoeloceras raquinianum (D'OrbIGNY) was found associated with the Eurhinosaurus remains of the Staffelegg. It is one of the few central European specimens of this species which has not been reworked, and is therefore of stratigraphic significance for the range of Catacoeloceras.

\section{Documentation of the record}

The concretion containing the Eurhinosaurus remains was discovered by Carol Spörli (Berikon/Wettingen/AG) in a claypit ca. $200 \mathrm{~m}$ north of the Staffelegg-pass at an altitude of $621 \mathrm{~m}$ in the summer 1981 (Figs. 1, 2; Streif, 1981; Gygi \& Rieber, 1988).

Fig. 1 Location of the claypit at Staffelegg

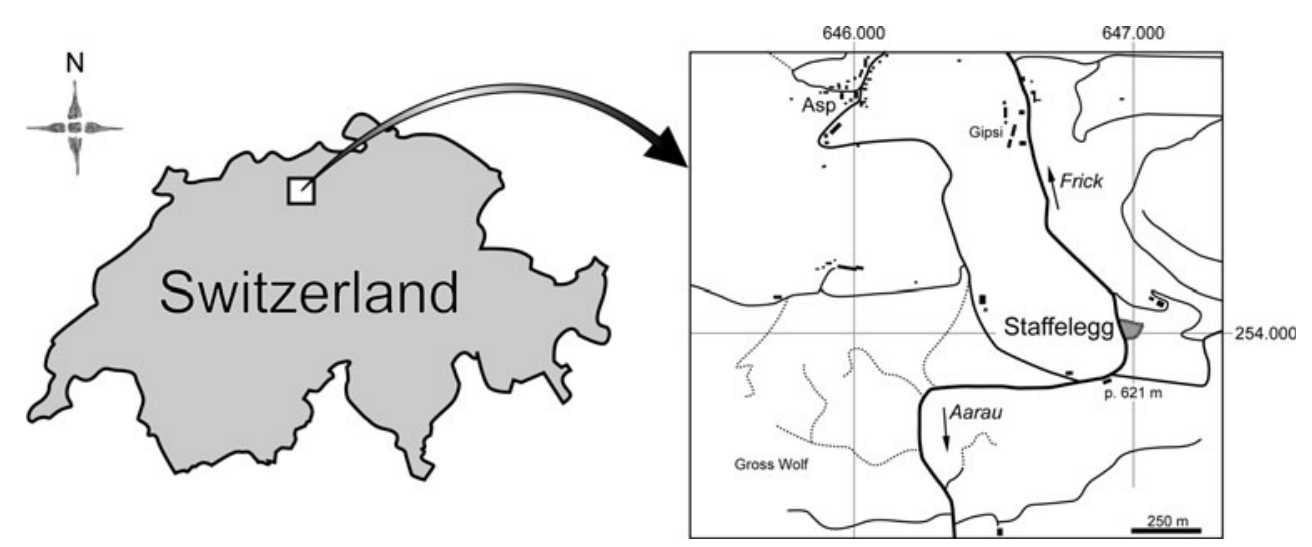




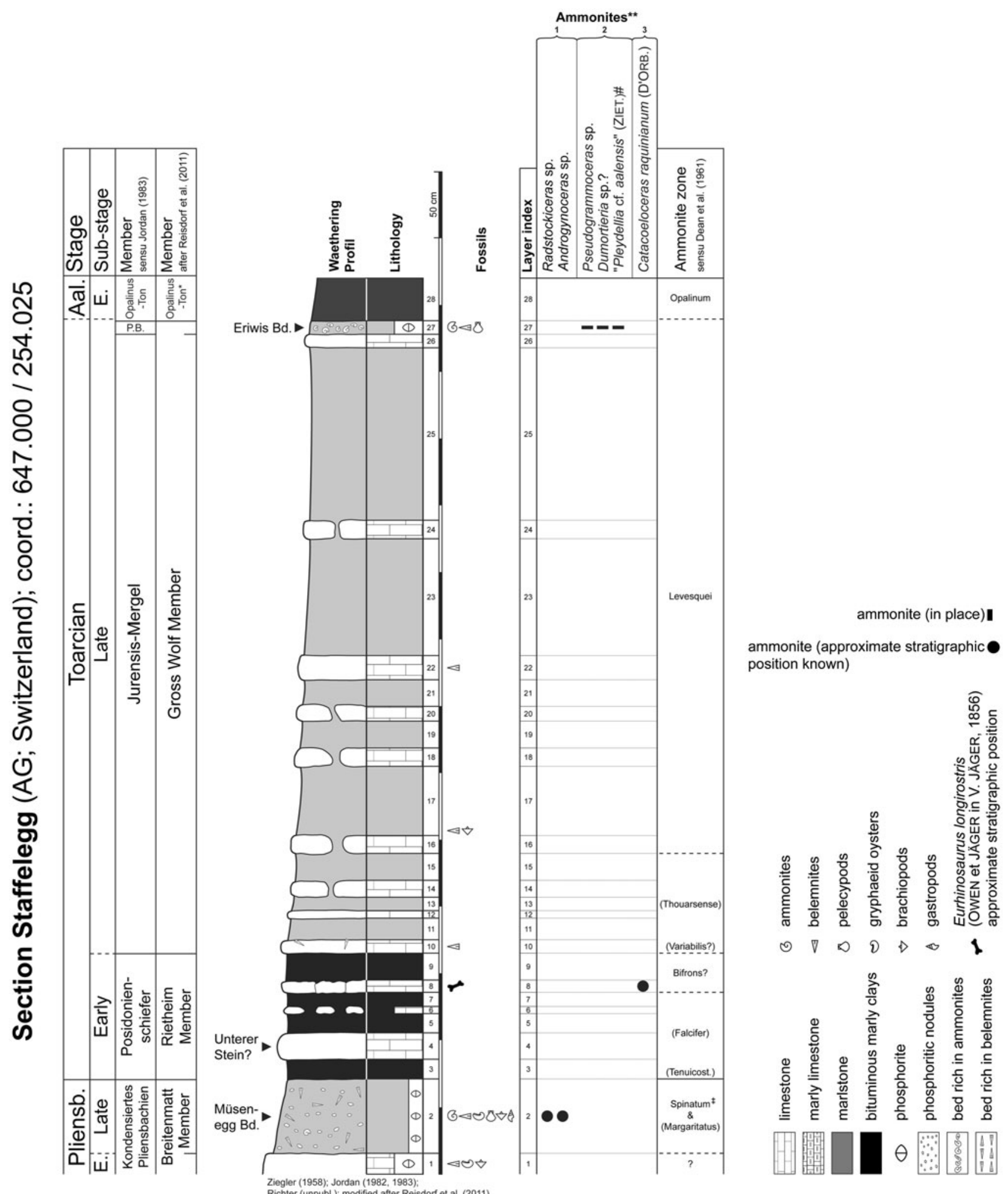

Fig. 2 Detailed stratigraphy of the Staffelegg claypit section where layers of the Late Pliensbachian to the Late Toarcian were exposed (today largely covered by scree; modified after Jordan 1983; H. Richter, pers. comm. 1987); *Opalinus-Ton sensu Wetzel and Allia (2003); **Data from (1) Jordan (1983), (2) Ziegler (1958), (3) this paper; Aal. Aalenian; Bd. bed; P.B. "Pleydellienbank"; †loosely collected Pleuroceras sp. at the "Staffelberg" (collection of the Geologisches Institut der ETH Zürich; see Jordan 1983); \#after Schulbert (2001): Cotteswoldia aalensis (ZIET.); ammonite zones in parentheses were not verified in the studied section 


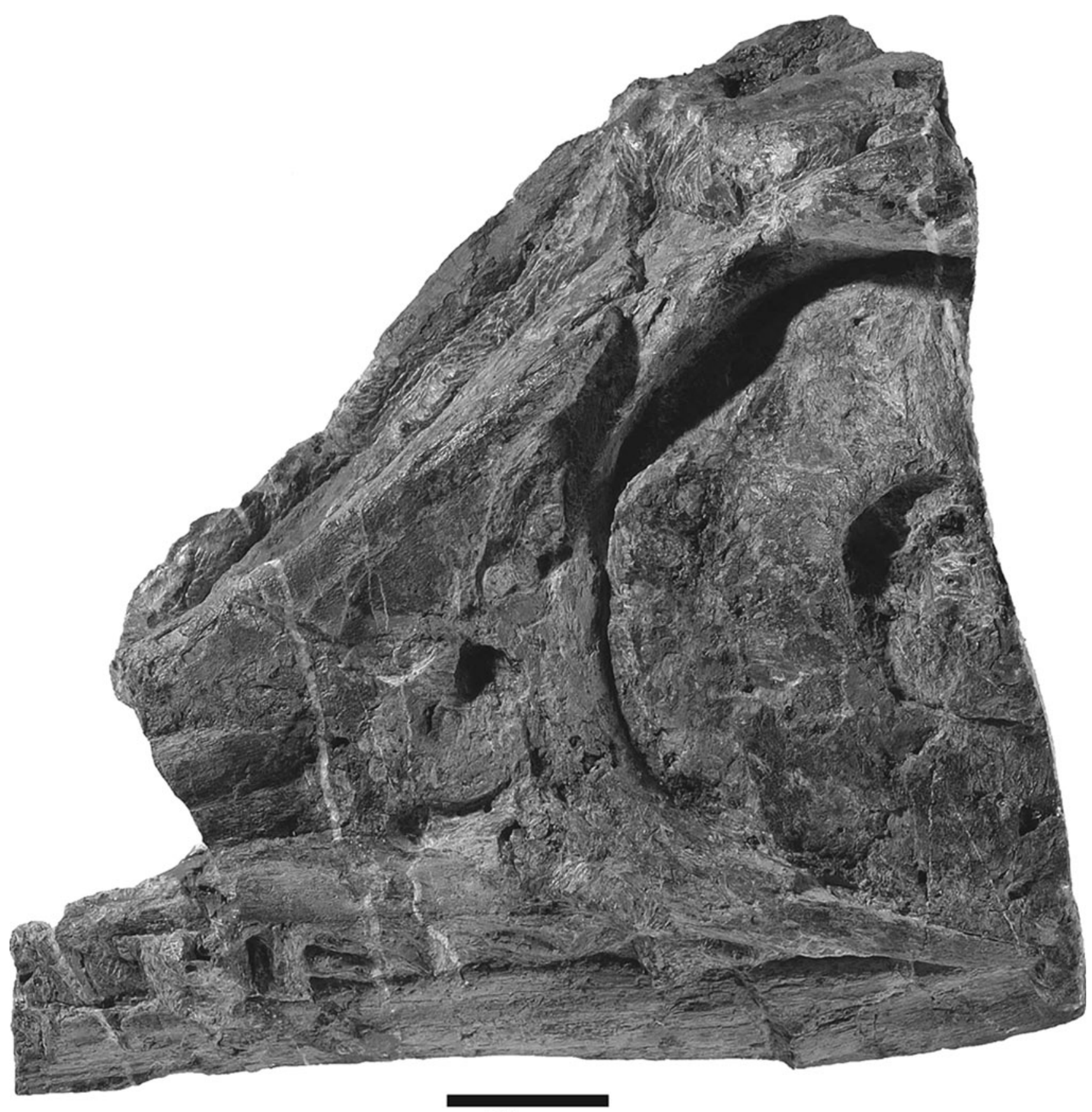

\section{$30 \mathrm{~mm}$}

Fig. 3 Skull of Eurhinosaurus longirostris (Owen et Jaeger in von Jaeger, 1856) from the Rietheim Member of the Staffelegg Formation (Bifrons or Variabilis zone Early/Late Toarcian) of Staffelegg,

The claypit is situated next to the Staffelegg road (Swiss coordinates: 647.000/254.025). Ernst Hofstetter (Bellikon/ AG) identified the specimen as an ichthyosaur and shortly thereafter, it was handed over to the Paläontologisches Institut und Museum der Universität Zürich. It was cut into several slices and the polished surfaces covered with varnish. 20 years later, the specimen was passed on to the
Canton Aargau, Switzerland. Note the exceptionally large orbits and the tiny supratemporal fenestra characteristic of the taxon

museum "naturama Aarau" (register number PIMUZ A/III 0749). In 2004, Ben Pabst (Zürich) started its preparation by gluing the slices of the concretion together. An additional fragment of the concretion is also available.

The slightly weathered limestone concretion is grey to brown with reddish traces of oxidised pyrite. The host sediment is a wackestone. Calcite-filled veins run in a 


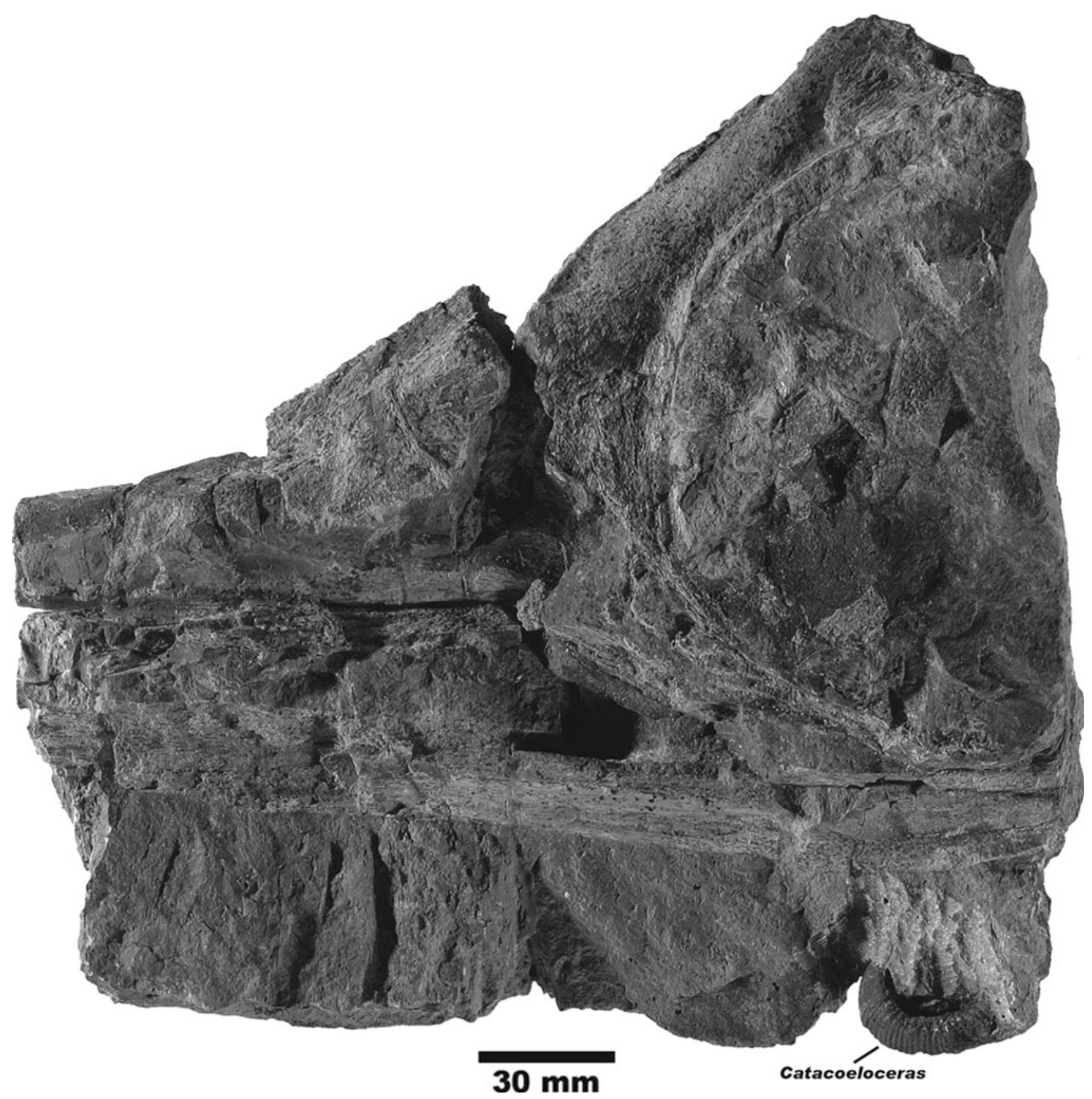

Fig. 4 Internal surface of the same specimen as in Fig. 3 seen in external view. Note again the huge orbit, as well as the comparatively small and weakly developed mandible

obtuse angle to the longitudinal axis of the skull (Fig. 3). Most of the skull bones are articulated, but in section, minor fractures and dislocations of some bones are visible (Figs. 3, 4). The fractures crossing the bones display traces of more intense weathering. All ichthyosaur- and invertebrate-remains associated with this concretion are threedimensionally preserved (including one ammonite; see "geological setting"). Small gastropods of the genus Coelodiscus are the most abundant macrofossils in this concretion (Figs. 4, 5).
Skull remains of a second Early Toarcian ichthyosaur (PIMUZ A/III 0749) were found in a limestone concretion in the same claypit on the Staffelegg by Hans Rieber (Paläontologisches Institut und Museum der Universität Zürich). The largely disarticulated skull was prepared, but no associated biostratigraphically useful macrofossils were found. Until this study, it was assumed that all these skull remains found by Carol Spörli and Hans Rieber belonged to one individual. The dimensions of the skull bones and the double presence of some bones, however, clearly show 

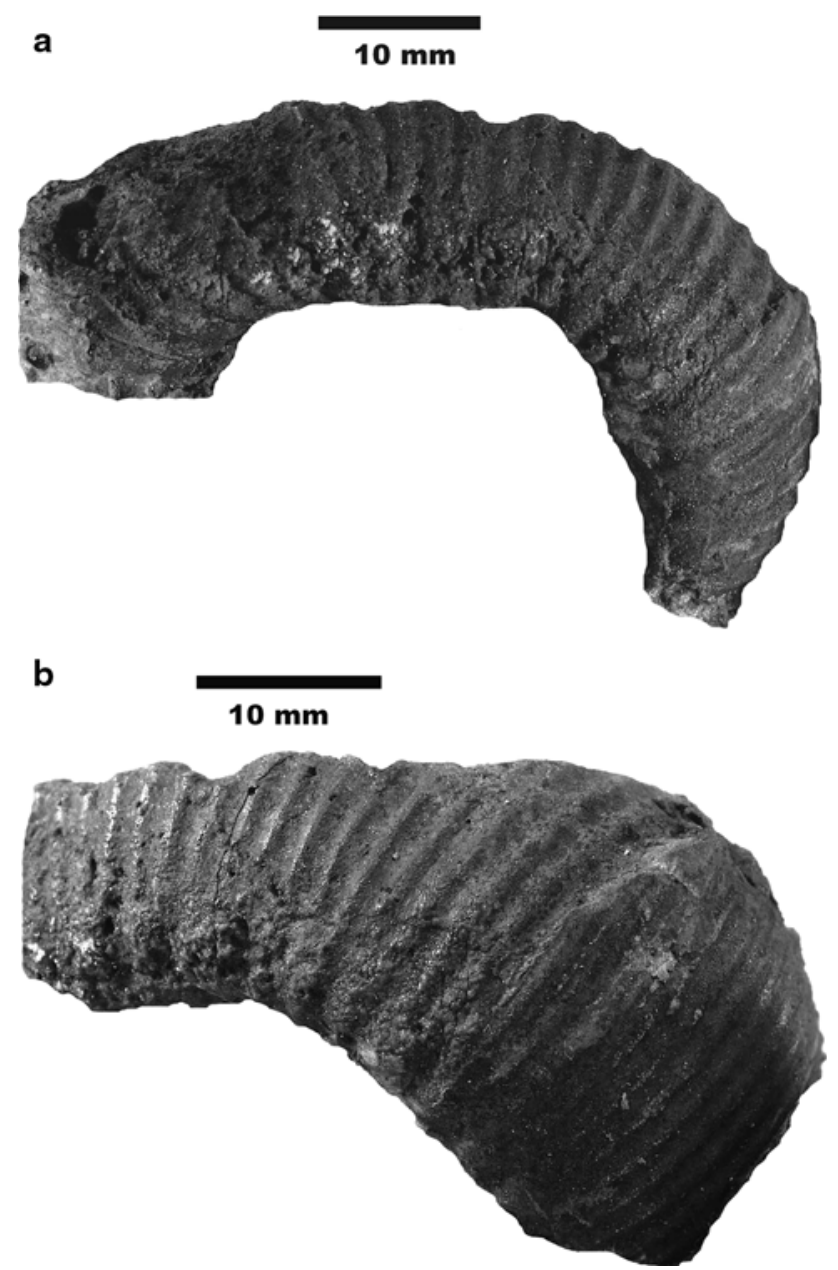

Fig. 5 Catacoeloceras raquinianum, lateral (a) and ventral view (b). This ammonite from the boundary of the Bifrons/Variabilis zones was found in association with the remains of Eurhinosaurus longirostris (see Fig. 4)

that these remains belong to two different skulls, and represent two distinct taxa. Therefore, the precise biostratigraphic origin of the skull remains found by Hans Rieber is unclear.

\section{Geological setting}

Staffelegg is located in the eastern Folded Jura northeast of the Einolte-Benken-Herzberg-domain. To the northeast, this block is delimited by the $\mathrm{N} 120^{\circ} \mathrm{E}$-trending Asptransverse fault. Along this fault, several small blocks with strata of Early to Middle Jurassic age crop out. The tectonic relationships between these blocks, their internal structure as well as their precise stratigraphy are difficult to determine because of the intense tectonic overprint (e.g., Merian, 1852; Amsler, 1915; Gsell, 1968; Maubeuge, 1979; Diebold et al., 2006).
Close to the Staffelegg-Pass, an occurrence of Early Aalenian mudstone was exploited for clay; there strata of middle to latest Early Jurassic age as well as the Early to Middle Jurassic boundary were exposed (e.g., Ziegler, 1967; de Quervain, 1969: 224 p; Geyer et al., 2003: 436 p). This section was studied in detail by Ziegler (1958), Maubeuge (1979), Jordan (1983) and Gygi and Rieber (1988). In the last few years, this claypit was exploited only sporadically and therefore, this part of the section is today largely covered by scree. Consequently, the description of the section presented below is exclusively based on published and unpublished data of previous workers (Fig. 2).

Facies and fossil content of the older Early Jurassic deposits (= Hettangian to Pliensbachian) in the Staffelegg area were described by Merian (1852), Heer (1865: 92), Moesch (1867), Erni (1910), Amsler (1919), Maubeuge (1979) and Jordan (1983). In this area, the entire Early Jurassic succession is about $25 \mathrm{~m}$ thick. In contrast to the table of the most important outcrops of the Staffelegg-area published by Amsler (1919), Early Hettangian strata do occur west of the Staffelegg (see Heer, 1865: 92; Erni, 1910: 43; Jordan, 1983; Wetzel et al., 1993). A nearly complete Early Jurassic section was exposed approximately $3 \mathrm{~km}$ east of the Staffelegg-Pass at "Buessge" (Jordan, 1983; Reisdorf et al., 2011). This section represents the type-locality of the Staffelegg Formation substituting the previously used informal stratigraphic unit "Lias" for the Early Jurassic (Reisdorf et al., 2011).

\section{Sedimentology and stratigraphy of the Staffelegg section}

\subsection{Breitenmatt Member and Müsenegg Bed}

At the Staffelegg claypit, Jordan (1983) found a light greyish, micritic and phosphoritic limestone as the oldest layer in an apparently tectonically unaltered partial section (Fig. 2). This limestone belongs to the Breitenmatt Member and is Early Pliensbachian in age (previously "Kondensiertes Pliensbachien" after Jordan, 1983). According to Reisdorf et al., (2011), the Breitenmatt Member is represented in the Folded Jura by a thin interval of limey marls and phosphoritic nodular limestones rich in macrofossils.

The Müsenegg Bed (Late Pliensbachian; previously "Kondensiertes Pliensbachien" after Jordan, 1983) represents the uppermost bed of the Breitenmatt Member in the Folded Jura (Reisdorf et al., 2011). The Müsenegg Bed in the Staffelegg section is a $55 \mathrm{~cm}$ thick, grey marl horizon, which contains phosphoritic concretions of one to a few centimetres in diameter and abundant belemnite rostra as well as gryphaeid oysters (see Jordan, 1983). The 
taphocoenosis of the Müsenegg Bed witnessed reworking during the Late Pliensbachian. Here, Jordan (1983) discovered the ammonite Radstockiceras sp., an index fossil of the basal Pliensbachian Jamesoni zone.

\subsection{Rietheim Member}

The Rietheim Member (Early Toarcian; previously "Posidonienschiefer" sensu Kuhn \& Etter, 1994) displays a clearly different, darker colour than the Müsenegg Bed although the bitumen content is lower in the Staffelegg section than elsewhere in northern Switzerland (see Gygi \& Rieber, 1988; Kuhn \& Etter, 1994). At least three limestone beds occur in this maximally $95 \mathrm{~cm}$ thick interval (H. Richter, pers. comm. 1987; Fig. 2). Jordan (1983) described an up to $3 \mathrm{~cm}$ thick jet-horizon from the base of the Rietheim Member. Maubeuge (1979) characterised the lowermost of the three limestone layers as "Stinkkalk". According to its stratigraphic position, this layer might be the stratigraphic equivalent of the Unterer Stein of Oppel (1856-1858), a lithostratigraphic index horizon of the Falcifer zone of supraregional importance (Kuhn \& Etter, 1994; Reisdorf et al., 2011). The upper two limestone layers have a less regular, often nodular appearance.

The previously mentioned dactylioceratid ammonite, which was associated with the Eurhinosaurus remains, is of significance with respect to date both the ichthyosaur skull remains and the biostratigraphic limits of the Rietheim Member at the Staffelegg. There are only remains of about one half of the moderately deformed exterior whorl, but the complete ammonite would have had a diameter of ca. $38 \mathrm{~mm}$ (Fig. 5). Its whorl cross-section is low and wide, of coronate type. There are strong ribs which bifurcate or rarely trifurcate, and the branching points of the ribs bear small tubercles. The ribs are straight across the venter. About 16 primary ribs can be counted in an incomplete semi-whorl. About 26 secondary ribs correspond to 12 primary ribs. The shape of the entire ammonite was moderately evolute and somewhat cadiconic. The lateral surface is strongly inclined towards the umbilicus below the branching points of the ribs. At a diameter of about $37 \mathrm{~mm}$, the umbilical width was probably $20 \mathrm{~mm}$, the whorl height about $7 \mathrm{~mm}$. At $27 \mathrm{~mm}$ diameter, the whorl width is about $16.5 \mathrm{~mm}$, its height amounts also to about $7 \mathrm{~mm}$ (probably due to compression). The specimen can, among Toarcian dactylioceratids, referred to the genus Catacoeloceras BuCKMAN, 1923 (Schmidt-Effing 1972; Schlegelmilch 1992). The small tubercles at the branching points as well as the rather common occurrence of trifurcate ribs indicate that the specimen represents Catacoeloceras raquinianum (D'ORBigny, 1844; Riegraf 1986). Comparison of the tentative measurements obtained from this specimen with those of three specimens of the same species provided by
Schlegelmilch (1992) and numerous specimens studied by Hengsbach (1985) confirm this assignment. The umbilical width divided by the diameter of the present specimen is about 0.54 compared to $0.40-0.55$ in the specimens of Schlegelmilch (1992) and 0.35-0.48 for the specimens studied by Hengsbach (1985). The slight discrepancy can be easily attributed to the deformation of the outer whorl, which yields a value that is somewhat high. The height of the outer whorl divided by the diameter is 0.18 in the present specimen, but originally was about $0.25-0.30$, accounting for the deformation. Values obtained by Hengsbach (1985) range between 0.25 and 0.43 . At any rate, variability in this species regarding the whorl crosssection is so large (Hengsbach 1985) that slight differences certainly do not hamper the identification.

The precise stratigraphic position of Catacoeloceras raquinianum is still unclear. Riegraf (1986) used this species as index for the late Bifrons zone (Early Toarcian) while Rieber (1973) and Hengsbach (1985) share the opinion that its stratigraphical range extends into the Variabilis zone (Late Toarcian, see below). Consequently, it is not possible to determine the position of the upper boundary for the Late Toarcian in the Staffelegg section, neither by this specimen collected from scree nor by data from Ziegler (1958), Maubeuge (1979) and Jordan (1983). It is conceivable that the Early/Late Toarcian-boundary is located in the black shale facies of the Rietheim Member without significant lithological change (e.g., Richter, 1987; see below).

\subsection{Gross Wolf Member}

The Gross Wolf Member (previously "Jurensis-Mergel" sensu Jordan 1983) doubtlessly belongs to the Late Toarcian. It is composed of dark to light grey, fossiliferous marls with thin interbeds of light greyish to bluish-greyish, fine-grained limestone or nodular limestone layers, marls and limestones may contain pyrite, and ammonites and belemnites are abundant (Reisdorf et al., 2011). A $20 \mathrm{~cm}$ thick marl-layer rich in ammonites, the Eriwis Bed (previously "Pleydellienbank" after Jordan 1983; Geyer et al., 2003; Reisdorf et al., 2011) overlies the topmost massive limestone layer. According to Jordan (1983), the Late Toarcian is $4.8 \mathrm{~m}$ thick in this section, where it was completely exposed, apparently without tectonically induced duplication of layers.

\section{Systematic palaeontology}

Order Ichthyosauria DE BlainvilLe, 1835

Family Leptonectidae MaIsCh, 1998

Genus Eurhinosaurus ABEL, 1909 
Type species Eurhinosaurus longirostris Owen et Jaeger in von Jaeger, 1856

\subsection{Description}

After preparation the specimen is preserved in two pieces. One shows the external surface of the bones of the skull and lower jaw (Fig. 3), whereas the other largely shows only impressions and cross-breaks through bones of the mandible and the pre- and circumorbital elements (Fig. 4).

The preserved portion of the left mandibular ramus which extends for a length of $204 \mathrm{~mm}$ is very low, slender and appears reduced in height and diameter as compared to the size of the skull if compared to other parvipelvian ichthyosaurs. The height of the mandible along the anterior cross break is $19 \mathrm{~mm}$. At the level of the anterior orbital margin it is $24 \mathrm{~mm}$.

Five mandibular teeth are identifiable, but none are well preserved. The anteriormost tooth is preserved in situ and positioned level with the anterior cross break. It lacks most of the crown. The second and third preserved teeth are displaced laterally. The crown of the second preserved tooth is relatively well preserved. The enamel of the crown is macroscopically smooth (even with a hand lens with tenfold magnification there are no identifiable striations). Horizontal concentric striations, a widespread feature in Eurhinosaurus, are not clearly identifiable, probably due to bad preservation. The crown is slender and straight. It is distinctly more slender than the root, but there is no distinct neck developed between the two. Of the fourth preserved tooth, which is still in situ, there are also some remains of the crown but most of the enamel is lost. The fifth tooth has, again, been laterally displaced.

In the upper jaw, ten teeth, all of which are located in the maxilla, can be identified. They extend from the anterior cross break to the level of the anterior orbital. The fourth preserved tooth shows a slender, narrow and almost straight crown. What remains of the enamel is also completely smooth. All teeth are quite small; the longest preserved crown has a length of only $12.5 \mathrm{~mm}$.

The anterior half of the left orbit is preserved. It appears to have been unusually large, but incomplete preservation hampers to obtain meaningful ratios. Its height along the posterior cross break is $130 \mathrm{~mm}$. The length of the orbit at that point is $78 \mathrm{~mm}$ (the entire orbit was thus probably $140-150 \mathrm{~mm}$ in length). The sclerotic ring consists of large plates most of which are badly damaged. Its anterior half is preserved. About eight plates can be identified, so the complete ring should have consisted of about 14-16 plates. The largest and best-preserved plate has an axial length of about $47 \mathrm{~mm}$. The internal diameter of the sclerotic ring is small. Along the posterior cross break it is only $49 \mathrm{~mm}$.
The internal aperture is preserved for a length of $28.5 \mathrm{~mm}$. It is unlikely that it was more than $50 \mathrm{~mm}$ long originally. The sclerotic ring is only moderately vaulted, probably a result of deformation.

Of the premaxilla, only the posteriormost portion is preserved and there are no remnants of the premaxillary dentition, as the maxilla forms the alveolar margin up to the anterior preserved end of the specimen. Towards the nasal, the suture of the premaxilla turns distinctly ventrally in its posterior part. The maxillary suture is straight. The posterior termination of the premaxilla cannot be determined with certainty. The subnarial and supranarial processes cannot be clearly identified.

The position and size of the external narial aperture is unclear. The most plausible interpretation of the narial area is, that the external naris was a relatively large and semisubdivided aperture with a ventral margin formed largely by the maxilla, and that the keyhole-shaped opening described above forms part of it, whereas the rest is largely obscured. The entire structure is referred to as the "pseudonaris" here, because of the aforementioned uncertainties.

The maxilla is $15 \mathrm{~mm}$ in height directly anterior to the "pseudonaris". Its lateral surface is strongly inclined ventrolaterally, which may be a result of deformation. Posterior to the "pseudonaris", the maxilla forms a long, posteroventrally inclined, interdigitating suture towards the lacrimal, which can be traced for a length of about $45 \mathrm{~mm}$ before the jugal inserts between the two bones. The entire suborbital process of the maxilla, which is strongly convex transversely on its ventral side, extends posterior to the anterior orbital margin for about $63 \mathrm{~mm}$ and contacts the jugal. The jugal ends far behind the anterior orbital margin and clearly had no contact with the premaxilla. Anteriorly, the jugal is overlapped by the lacrimal dorsally and the maxilla ventrally. The suborbital portion of the jugal is markedly convex transversely on its ventral side. Its lateral margin forms a distinct crest; the dorsal surface is concave. The cross-section is dorsoventrally flattened.

The nasal bears a prominent crest where its dorsal and lateral surfaces meet, forming an angle of about $90^{\circ}$. The dorsal surface of the nasal is completely flat transversely in the pre- and supraorbital portions of the skull roof, but shows a slight longitudinal concavity. Posteroventrally, the nasal forms a short sutural contact with the lacrimal posterodorsal to the "pseudonaris", but the two bones remain largely separated by the intervening prefrontal. Apparently there is little overlap between the nasal and lacrimal. The ventral suture towards the premaxilla cannot be completely followed because of the unclear "pseudonarial" region. Nonetheless it is likely that the nasal forms the dorsal margin of the naris in this area. The lateral surface of the nasal is largely flat and inclined lateroventrally. There is a slight depression ventral to the dorsolateral nasal crest. 
Posteriorly, the nasal overlaps the prefrontal. It already terminates shortly behind the anterior orbital margin and its supraorbital portion is thus probably quite incompletely preserved.

Part of the right nasal is also preserved. The median suture between both nasals can be traced for a length of more than $90 \mathrm{~mm}$ from the anterior preserved end of the skull backwards. Anteriorly, the nasal is only $16 \mathrm{~mm}$ wide. It increases in width posteriorly, measuring $29 \mathrm{~mm}$ at the level of the anterior orbital margin.

The lateral surface of the lacrimal shows no marked antorbital crest, only a very slight bulge, behind which the lacrimal surface slopes gently posteromedially towards the orbit. The suture towards the prefrontal apparently takes a zig-zag pattern but is ill-defined. The suture with the nasal is short, reduced almost to a point-contact, at least as far as it is clearly visible. It was probably longer originally, but it remains unclear whether a triangular bone fragment anterodorsal to the "pseudonaris" belongs to the lacrimal or the nasal. If the latter was the case, the lacrimal-nasal-suture would have been considerably longer. Anteriorly the lacrimal turns around the dorsal part of the "pseudonaris" with concave curvature. The suborbital portion of the lacrimal has a slightly convex dorsal surface.

The prefrontal forms a sharp laterally protruding ridge along the dorsal orbital margin. Anterior to this ridge, paralleling the border towards the lacrimal, there is a deep furrow, which gradually shallows posterodorsally. The portion of the prefrontal anterior to this furrow, which is situated behind the nasal is deeply concave. Behind the posterior preserved end of the nasal, the dorsal surface of the prefrontal ascends mediodorsally until about $8 \mathrm{~mm}$ medial to the dorsal orbital margin a conspicuous ridge is formed. This ridge is probably best interpreted as marking part of the sutural facet with the now missing part of the supraorbital portion of the nasal. The ridge extends almost to the parietal, indicating that the nasal very probably contacted the parietal originally.

Part of the postfrontal is preserved but seems to be somewhat dislocated, as it strongly protrudes above the prefrontal. The lateral margin of the postfrontal is narrow and forms a sharpened ridge. The postfrontal overlaps the prefrontal. Anteriorly it ends, as preserved, at the level of the anterior margin of the internal sclerotic aperture. The dorsal surface of the postfrontal is convex both transversely and longitudinally. There is a shallow groove somewhat medial to the orbital margin. The postfrontal forms the lateral margin of the tiny fenestra supratemporalis. The fenestra was probably at least somewhat larger originally, as the left parietal seems to be somewhat dislocated laterally, obscuring parts of it. As far as it is preserved, the fenestra temporalis is only a few mm wide anteriorly and
$12 \mathrm{~mm}$ wide at the posterior preserved end of the skull. Its preserved length is $16 \mathrm{~mm}$.

The left parietal is almost complete anteriorly. Its anterior margin strongly overlaps the prefrontal, which may in part result from the dislocation in this region of the skull. The anterior border towards the prefrontal is strongly inclined anterolaterally. The medial margin of the parietal is straight, contacting the mangled remnants of its counterpart. The foramen parietale cannot be identified. Anterolaterally, the dorsal surface of the parietal is quite flat, but bulges slightly towards the midline. Nevertheless, there is no clear crista sagittalis, only a slightly inclined plane.

The considerably damaged remains of the lower jaw are broken in two. The anterior portion clearly shows three elements. The dorsalmost lamella represents the dentary. It is flat and low and tightly apressed onto the underlying supraangular. It terminates $15 \mathrm{~mm}$ anterior the large crossbreak, but originally quite certainly extended further posteriorly, although it flaked off from the underlying bones. The dentary is only $11 \mathrm{~mm}$ high at its preserved anterior end, and $10 \mathrm{~mm}$ high posteriorly, so it is very gracile and low for its preserved length. The angular can be seen anteriorly as a minute splinter of bone for a length of $55 \mathrm{~mm}$. Posteriorly it seems to be entirely missing, so the mandible was probably somewhat higher originally in its posterior part. Most of the preserved lateral mandibular surface is formed by the supraangular. The dorsal preserved margin of the supraangular (which probably does not entirely correspond to the original dorsal margin) forms a lateral ridge that becomes narrower and sharper posteriorly. Below this ridge, the lateral surangular surface is dorsoventrally convex. A weak furrow below the lateral supraangular ridge probably corresponds to the fossa supraangularis. Nothing is visible of the fossa dentalis, which is quite certainly attributable to bad preservation. The splenial cannot be identified beyond doubt, except for some remnants in the counterpart of the specimen, which shows the impression and some bone fragments of the internal surface of the lower jaw.

The counterpart of the specimen shows few details (Fig. 4). The impression of the internal surface of the prefrontal shows that it was a huge element which extended far below the nasal and even the parietal, even to the preserved posterior margin of the skull. Internally it forms an anteriorly convex suture towards the postfrontal at the level of the anterior margin of the internal sclerotic aperture. The ventral surface of the prefrontal was strongly concave, from the anterior contact with the lacrimal up to the posterior preserved end. The ventral surface of the postfrontal, in contrast, is rather convex. The frontal can also be identified in the impression of the underside of the skull-roof. It is a narrow bone that contacts the prefrontal laterally in a rather straight, densely serrated suture. Its 
ventral surface is strongly inclined medioventrally. In an articulated complete skull, the frontal would probably not have been exposed externally. Anteriorly, the frontal is only $19 \mathrm{~mm}$ wide; posteriorly, it narrows to a lanceolate tip. Anteriorly it extends up to the (presumed) level of the external naris; posteriorly, it terminates shortly before the level of the prefrontal-postfrontal suture. The internal surface of the supraangular is strongly concave in its middle (a strong ridge is formed by the remaining impression), indicating the course of the Meckelian canal, which is visible for a length of $151 \mathrm{~mm}$. The canal gets shallower and wider posteriorly.

\subsection{Comparison}

Of the five ichthyosaur genera currently recognized from the Early Toarcian (see Maisch \& Matzke, 2000, McGowan \& Motani, 2003, Maisch, 2008), the skull can be identified as Eurhinosaurus ABEL, 1909. The skull shows the following leptonectid autapomorophies: slender, elongate and rather straight teeth without distinct surface ornamentation of the crown, very large orbits, small fenestra supratemporalis. Although other characteristics of the leptonectids, such as the morphology of the cheek region and of the quadratojugal in particular cannot be investigated, it is clear, that the specimen can only be referred to this family. Eurhinosaurus longirostris is the only leptonectid species currently known from the Toarcian. The extreme reduction of the size of the fenestra supratemporalis and strongly reduced external exposure of the frontal are considered autapomorphic for this taxon. Consequently among known ichthyosaurs, the Staffelegg skull can only be referred to that genus and species, representing its first record from Switzerland.

\section{Discussion}

As far as documented discoveries of Early Jurassic ichthyosaurs and the respective accessible outcrops are concerned, the canton Aargau is the most important and productive area of Switzerland. Among Early Jurassic ichthyosaur localities, especially the claypits of Frick and Staffelegg stand out, as well as Betznau near Böttstein (Moesch, 1867; Maisch \& Reisdorf, 2006a, b; Maisch et al., 2008). Further specimens have been described from Bütz/Sulz (Moesch, 1867; Peyer \& Koechlin, 1934) and Schupfart (detailed informations on these fossil localities are given in Maisch \& Reisdorf, 2006a, b).

Detailed examinations of the stratigraphic framework of these articulated ichthyosaur discoveries have added several previously unknown facts to our knowledge of the Early Jurassic of northwestern Switzerland.
1. In the Folded Jura (section Unter Hauenstein), dating of a nearly vertically embedded incomplete skeleton of a Leptonectes tenuirostris required a detailed analysis of the stratigraphic, taphonomic and diagenetic situation (Maisch \& Reisdorf, 2006a, b; Reisdorf, 2007; Wetzel \& Reisdorf, 2007). In this context, Maisch \& Reisdorf $(2006 \mathrm{a}, \mathrm{b})$ showed the presence of the Tenuicostatum zone by a Dactylioceras sp. in the eastern Folded Jura. This specimen is flattened, typical for Early Toarcian bituminous marls (c.f., Seilacher 1990; Kuhn \& Etter, 1994). Its preservation and its host rock rules out reworking. This ammonite displays a mode of ribbing characteristic for early species of Dactylioceras of the early Early Toarcian, thus excluding a Pliensbachian age (pers. comm. R. Schlatter 2001; von Hillebrandt 1981: 576; Maisch \& Reisdorf, 2006a, b). The discovery of this Dactylioceras is of importance because previously, evidence for the presence of the Tenuicostatum zone in northern Switzerland had only been documented from the Klettgau area (Schlatter, 1982). The detection of this zone with the aid of ostracods by Richter (1987) was challenged by Kuhn and Etter (1994).

2. The specimen of Catacoeloceras raquinianum (D'OrbignY; Figs. 4, 5) which was associated with the remains of an Eurhinosaurus from the Staffelegg is one of the otherwise extremely rare ammonites from near the Bifrons to Variabilis zone-boundary (Early to Late Toarcian-boundary) of the Folded Jura which has not been reworked (see below). Unreworked indexammonites of the Bifrons zone such as "Ammonites" bifrons, "Ammonites" communis, "Coeloceras (Dactylioceras)" commune were mentioned only by Heer (1865: 99), Moesch (1874), Senftleben (1923) but later records are lacking.

Additional ammonite specimens of the Bifrons zone from the Folded Jura were convincingly shown to have been reworked (e.g., Erni in Mühlberg, 1915; Imhof in Jordan, 1983; Richter, 1987; Kuhn \& Etter, 1994). Usually, these reworked ammonites are three-dimensionally preserved steinkerns. They were re-deposited during the Variabilis zone in a layer of a few centimetres thickness, which forms the Erlimoos Bed in the Hauenstein area above a unconformity of early Late Toarcian age (Reisdorf et al., 2011). This layer is usually encrusted by stromatiform algae and sponges (e.g., Jordan, 1983; Reisdorf et al., 2011). It is also remarkable that the Erlimoos Bed contains rather strongly corroded ichthyosaur remains (Meyer and Furrer 1995; Maisch \& Reisdorf, 2006a, b: table 1, locality "Fasiswald"; pers. comm. B. Hostettler 2004) in addition to reworked Pliensbachian and Early Toarcian ammonites. This faunal association suggests that these reworked, 
disarticulated skeletal remains (mainly vertebrae) of ichthyosaurs are of Early Toarcian or older age. This is also a likely hypothesis for the majority of the disarticulated ichthyosaur skeletal remains that have hitherto, albeit with reservations, been attributed to the "Kondensiertes Pliensbachien" (Pliensbachian) or the "Jurensismergel" and "Pleydellienbank" (Late Toarcian) (see Maisch \& Reisdorf, 2006a, b: table 1, locality "Erlimoos").

However, the high degree of articulation excludes that the taphocoenosis of the nodule of the ichthyosaur skull under consideration was reworked. The slight fracturing and minor dislocation of bones are interpreted as caused by compaction rather than reworking. This happened prior to complete cementation during burial diagenesis. Cross-cutting veins filled with white calcite are explained by mechanical stress after the formation of the concretion (e.g., Barker et al., 1997). Most likely, this stress was of tectonic origin due to Jura-thrusting.

The biostratigraphic position of the rare ammonite species Catacoeloceras raquinianum (D'ORBIGNY) sensu Hengsbach (1985: 377; = C. crassum Young and BIRD) is a matter of debate. Riegraf (1986) stressed that undoubtedly non-reworked Catacoeloceras raquinianum (D'ORBIGNY) has been discovered in southern Germany exclusively in the Crassum subzone (Bifrons zone, Early Toarcian). Riegraf (1986) has the same opinion for the northern Swiss Tabular Jura, namely RIEBER's "Bank 7" at Gipf which contains Nodicoeloceras sp., Mucrodactylites sp. and Osperlioceras sp. as well as Catacoeloceras cf. confectum BucKMAn $(=C$. raquinanum; Groupe Français d'Etude du Jurassique 1997: 30). However, Rieber (1973) dated this faunal association as Late Toarcian (early Variabilis zone). This is corroborated by the stratigraphic age given by the Groupe Français d'Etude du Jurassique (1997: 30) for Catacoeloceras dumortieri (MAubeugE). This is an ammonite species which apparently occurs also in "Bank 7" at Gipf (Rieber, 1973).

In northern France, Catacoeloceras occurs in condensed sequences of the latest Bifrons zone and the basal Variabilis zone (Gabilly, 1976). In southern Germany and northern Switzerland, Catacoeloceras is commonly found in reworked and condensed layers of the early Late Toarcian (Krumbeck, 1932; Jordan, 1983; Riegraf, 1986). Judging by the fossil record such condensated and reworked horizons in northern Switzerland are restricted to the Variabilis zone (earliest Late Toarcian). This applies for both the Erlimoos Bed and the Gipf Bed (Reisdorf et al., 2011).

Formation of the Erlimoos Bed and the Gipf Bed occured during a global sea-level-fall during the Variabilis zone (e.g., Hallam, 1988; Haq et al., 1988). This caused complete erosion of Early Toarcian sediments in areas west of the Staffelegg region (e.g., Hauenstein area; see above; Kuhn \& Etter, 1994). Since Rieber (1973) found several indications for a shallow marine environment, wave action which affected the sea-floor (e.g., ooids, questionable erosion surfaces, questionable stromatiform algae) and similar phenomena are also known from the Folded Jura (Jordan, 1983, Reisdorf et al., 2011), it seems reasonable to associate these taphocoenoses with reworking and/or condensation during the Variabilis zone as well. Such an interpretation is compatible with the stratigraphic range of Catacoeloceras raquinianum (D'ORBIGNY) as suggested by Riegraf (1986) for southern Germany and northern Switzerland.

The association of the articulated ichthyosaur skull in the concretion with a specimen of Catacoeloceras raquinianum (D'ORBIGNY) would have been suitable to test the positions of Hengsbach (1985) and Riegraf (1986), if the stratigraphic origin of the concretion was precisely known. Since it was collected from scree, it can only be excluded that these fossils were associated by reworking. A doubtless age determination on the level of an ammonite zone (Bifrons zone or Variabilis zone) is therefore not possible. Close to the Early to Late Toarcian boundary fits well with all possibilities and facts. Therefore, it remains unclear for now whether sediments of the Bifrons zone and the Variabilis zone are present in the Staffelegg-area and in which form they occur.

In the Staffelegg claypit a thickness of $4.8 \mathrm{~m}$ for the Gross Wolf Member was measured by Maubeuge (1979) and Jordan (1983), which is unusually high for the Folded Jura. Such and higher thicknesses have been documented for the Gross Wolf Member only in the Tabular Jura and Molasse basin so far (e.g., Reisdorf et al., 2011). In the eastern Folded Jura, its thickness normally ranges between only a few tens of centimetres and up to ca. $2.5 \mathrm{~m}$ (Jordan 1983). It is not clear how the thickness of the various ammonite zones contributes to the high thickness of the Gross Wolf Member in the Staffelegg section (the stratigraphic information of Maubeuge, 1979 on the onset of Late Toarcian ammonite associations lacks clarity). When comparing this situation with that of the Swiss Tabular Jura and of south-western Germany (Söll, 1965; Ohmert, 1976; Knitter \& Ohmert, 1983; Etter, 1990), it appears likely that the increased thickness of the Aalensis subzone accounts for the increased thickness.

The boundary between the Gross Wolf Member and the Opalinus-Ton sensu Wetzel and Allia (2003) is not identical with the biostratigraphic boundary between the Early and the Middle Jurassic: Ammonites of the Aalensis subzone (e.g., "Pleydellia" aalensis $=$ Cotteswoldia aalensis ZIET.) still occur in the lowermost centimetres of the Opalinus-Ton facies (Etter, 1990; Reisdorf, 2001). Maubeuge (1979) described ammonites of the Aalensis subzone from a part of the section well within the Opalinus-Ton several metres above the base of the Middle Jurassic but he 
mentioned the complex tectonic setting in the Staffeleggarea which most likely accounts for this phenomenon in that part of the claypit studied by him.

\section{Conclusions}

The stratigraphic situation of northern Switzerland shows that certain lithofacies-types, which have been defined for the subdivision of Early Toarcian sediments are of limited use for age determinations. Richter (1987) and Kuhn and Etter (1994) already showed clearly that the Early Toarcian sediments of the Folded Jura display significant lateral facies variations compared to the Tabular Jura, Klettgau area and southwestern Germany.

The host sediments of the ichthyosaur-bearing concretion from Staffelegg resemble deposits exposed in various stratigraphic levels of the Early Jurassic in northern Switzerland and southwestern Germany. Similar Coelodiscusrich limestone-layers occur in the Late Pliensbachian (Margaritatus zone; Reisdorf, 2007: 30), the Early Toarcian (Falcifer zone; Krumbeck, 1932; Kuhn and Etter, 1994) and Late Toarcian (Variabilis zone; Rieber, 1973). On the one hand, the Pliensbachian age can be excluded by the discovery of Catacoeloceras raquinianum (Early to Late Toarcian boundary region), but on the other hand, a more precise age determination of concretion and ichthyosaurbones is not possible. Nevertheless, this specimen of Eurhinosaurus is accordingly from the Early to Late Toarcian boundary and thus belongs to the youngest occurrences of this genus from the European mainland (e.g., Benton \& Taylor, 1984; Pharisat et al., 1993).

The Swiss specimen supports the status of Eurhinosaurus longirostris as a palaeobiogeographic very widespread ichthyosaur species in the Early Toarcian of Western Europe. Whereas other ichthyosaur taxa and many other marine reptiles of the Early Toarcian show a distinct provinciality (Godefroit 1994; Maisch and Ansorge 2004) this is not the case for E. longirostris. The species of the genera Temnodontosaurus and Stenopterygius appear to show some provinciality in the Western European Toarcian. Eurhinosaurus longirostris, to the contrary, has an unusually wide distribution, the genus being known from England, France, the Benelux, Southern and Northern Germany and Switzerland, i.e. all areas where substantial Toarcian ichthyosaur finds have been made so far. Only Stenopterygius quadriscissus and Hauffiopteryx typicus show a similarly wide distribution among Early Toarcian marine reptiles so far. Nevertheless it has to be considered that our current knowledge of Early Toarcian marine reptile faunas remains patchy and many historical finds (e.g. those from Northern England) are in dire need of revision. New material from France also suggests wider palaeogeographic distribution of some taxa than previously assumed (see Fischer et al., 2009). Therefore the hypothesis of ichthyosaur provinciality has to be tested in the light of new taxonomic revisions and new findings in the future.

Acknowledgments This study would not have been possible without the support of many people and institutions. U. Halder and R. Foelix (both "naturama Aargau") authorised the research on the ichthyosaur remains and organised their preparation, which was carried out by B. Pabst (Zürich). W. Gerber (Tübingen) took the photographs. The thoughtful reviews by P. Godefroit (Brussels), D. Martill (Portsmouth), and editorial work by M. J. Benton (Bristol) and D. Marty (Basel) helped much to improve the manuscript. The manuscript benefited from the critical comments of C. Klug (Zürich) and K. Waite (Stavanger). C. Spörli (Berikon/Wettingen/AG) and E. Hofstetter (Bellikon; Bezirksschule Aarau) provided detailed information on the discovery of the ichthyosaur remains. Bio- and lithostratigraphic data and fruitful discussions were provided by H. Furrer (Zürich), B. Hostettler (Glovelier), B. Imhof (Trimbach), P. Jordan (Zuchwil), H. Richter (Tübingen), H. Rieber (Zürich) and R. Schlatter (Leipzig). This study was financially supported by the Schweizerischer Nationalfonds zur Förderung der wissenschaftlichen Forschung (grants Nos. 20-50484.97, 2000-56640.99 and 2000-064567 to A. Wetzel) and the Freiwillige Akademische Gesellschaft (Basel). All these contributions are gratefully acknowledged.

\section{References}

Abel, O. (1909). Cetaceenstudien. 1. Mitteilung: Das Skelett von Eurhinodelphis cocheteuxi aus dem Obermiozän von Antwerpen. Sitzungsberichte der Kaiserlichen Akademie der Wissenschaften, Mathematisch-naturwissenschaftliche Klasse, 118, 241-253.

Amsler, A. (1915). Tektonik des Staffelegg-Gebietes und Betrachtungen über Bau und Entstehung des Jura-Ostendes. Eclogae Geologicae Helvetiae, 13, 377-488.

Amsler, A. (1919). Eine geologische Exkursion über die Staffelegg. Mitteilungen der Aargauischen naturforschenden Gesellschaft, $15,1-57$.

Barker, M. J., Clarke, J. B., \& Martill, D. M. (1997). Mesozoic reptile bones as diagenetic windows. Societe Géologique de France, 168, 535-545.

Benton, M. J., \& Taylor, M. A. (1984). Marine reptiles from the Upper Lias (Lower Toarcian, Lower Jurassic) of the Yorkshire coast. Proceedings of the Yorkshire Geological Society, 44, 399-429.

de Blainville, H. M. D. (1835). Description des quelques espèces de la Californie, précedée de l'analyse d'un système général d'érpetologie et d'amphibiologie. Nouvelles Annales du Muséum d'Histoire Naturelle, 4, 236-296.

de Quervain, F. (1969). Die nutzbaren Gesteine der Schweiz. Dritte, vollständig umgearbeitete Auflage (p. 321). Bern: Kümmerly \& Frey.

Diebold, P., Bitterli-Brunner, P., \& Naef, H. (2006). Geologischer Atlas der Schweiz 1:25000, Blatt 1069 Frick mit schweizerischem Anteil von Blatt 1049 Laufenburg (Atlasblatt 110), Erläuterungen. Wabern: Bundesamt für Landestopographie.

Erni, A. (1910). Das Rhät im schweizerischen Jura. Eclogae Geologicae Helvetiae, 11, 5-54.

Etter, W. (1990). Paläontologische Untersuchungen im Unteren Opalinuston der Nordschweiz. Ph.D. dissertation, University of Zurich, Zürich, Switzerland, $151 \mathrm{pp}$. 
Fischer, V., Guiomar, M., \& Godefroit, P. (2009). New data on the palaeobiogeography of Toarcian (Lower Jurassic) ichthyosaurs. In: P. Godefroit \& O. Lamber (Eds.), Tribute to Charles Darwin and Bernissard Iguanodons: new perspectives on Vertebrate Evolution and Early Cretaceous ecosystems, February 9-13, 2009: Programme, Abstracts and Field Trips Guidebook Brussels.

Fischer, V., Guiomar, M., \& Godefroit, P. (2011). New data on the palaeobiogeography of Early Jurassic marine reptiles: the Toarcian ichthyosaur fauna of the Vocontian Basin (SE France). Neues Jahrbuch für Geologie und Paläontologie, Abhandlungen, 261, 111-127.

Floquet, M., Cecca, F., Mestre, M., Macchioni, F., Guiomar, M., Baudin, F., et al. (2003). Mortalité en masse ou fossilisation exceptionnelle? Le cas des gisements d'âge toarcien inférieur et moyen de la région de Digne-Les-Bains (Sud-Est de la France). Bulletin de la Societe Géologique de France, 174, 159-176.

Furrer, H. (1958). Der Ichthyosaurus von Teysachaux. Mitteilungen der naturforschenden Gesellschaft in Bern, Neue Folge, 16, $75-80$.

Gabilly, J. (1976). Evolution et systématique des Phymatoceratinae et des Grammoceratinae (Hildocerataceae, Ammonitina) de la région de Thouars, stratotype du Toarcien. Mémoires de la Société géologique de France, Nouvelle Série, 54 (1975), 1-193.

Geyer, O. F., Schober, T., \& Geyer, M. (2003). Sammlung Geologischer Führer, Band 94, Die Hochrhein-Regionen zwischen Bodensee und Basel. Berlin: Gebrüder Borntraeger.

Godefroit, P. (1994). Les reptiles marins du toarcien (Jurassique inférieur) Belgo-luxemburgois. Mémoires pour servir à l'explication des Cartes Géologiques de la Belgique, 39, 1-98.

Groupe Français d'Etude du Jurassique (1997). Biostratigraphie du Jurassique Quest-Européen et Méditerranéen-Zonations paralléles et distribution des invertébrés et microfossiles. Bulletin des Centres de Recherches Exploration-Production Elf-Aquitaine, 17:1-440.

Gsell, F. (1968). Geologie des Falten- und Tafeljuras zwischen Aare und Wittnau und Betrachtungen zur Tektonik des Ostjura zwischen dem Unteren Hauenstein im $\mathrm{W}$ und der Aare im E. Ph.D. dissertation, University of Zurich, Zürich, Switzerland.

Gygi, R. A., \& Rieber, H. (1988). Der Aargauer Jura zwischen Laufenburg und Wildegg (Exkursion K am 31. März 1989. Jahresberichte und Mitteilungen des oberrheinischen geologischen Vereines, 71, 177-188.

Hallam, A. (1988). A re-evaluation of the Jurassic eustasy in the light of new data and the revised Exxon curve. Society of Economic Paleontologists and Mineralogists. Special Publication, 42, 261-273.

Haq, B. U., Hardenbol, J., \& Vail, P. R. (1988). Mesozoic and Cenozoic chronostratigraphy and cycles of sea-level change. Society of Economic Paleontologists and Mineralogists. Special Publication, 42, 71-108.

Heer, O. (1865). Die Urwelt der Schweiz. Zürich: Schulthess.

Hengsbach, R. (1985). Die Ammonitengattung Catacoeloceras im S-französischen und S-deutschen Ober-Torarcien. Senckenbergiana Lethaea, 65, 347-411.

Jordan, P. (1983). Zur Stratigraphie des Lias zwischen Unterem Hauenstein und Schinznach (Solothurner und Aargauer Faltenjura). Eclogae Geologicae Helvetiae, 76, 355-379.

Knitter, H., \& Ohmert, W. (1983). Das Toarcium der Schwärze bei Badenweiler (Oberrheingebiet S Freiburg). Jahreshefte des Geologischen Landesamts Baden-Württemberg, 25, 233-281.

Krumbeck, L. (1932). Über den Lias von Kalchreuth bei Erlangen, besonders $\gamma$ und $\varepsilon$. Centralblatt für Mineralogie, Geologie und Paläontologie in Verbindung mit dem Neuen Jahrbuch für Mineralogie, Geologie und Paläontologie, Abteilung B, Jahrgang, 1932(43-65), 73-90.
Kuhn, O., \& Etter, W. (1994). Der Posidonienschiefer der Nordschweiz: Lithostratigraphie, Biostratigraphie und Fazies. Eclogae Geologicae Helvetiae, 87, 113-138.

Maisch, M. W. (1998). A new ichthyosaur genus from the Posidonia Shale (Lower Toarcian, Jurassic) of Holzmaden, SW-Germany with comments on the phylogeny of post-Triassic ichthyosaurs. Neues Jahrbuch für Geologie und Paläontologie, Abhandlungen, 209, 47-78.

Maisch, M. W. (2008). Revision der Gattung Stenopterygius Jaekel, 1904 emend. von Huene, 1922 (Reptilia: Ichthyosauria) aus dem unteren Jura Westeuropas. Palaeodiversity, 1, 227-271.

Maisch, M. W., \& Ansorge, J. (2004). The Liassic ichthyosaur Stenopterygius cf. quadriscissus from the lower Toarcian of Dobbertin (northeastern Germany) and some considerations on lower Toarcian marine reptile paleobiogeography. Paläontologische Zeitschrift, 78, 161-171.

Maisch, M. W., \& Matzke, A. T. (2000). The Ichthyosauria. Stuttgarter Beiträge zur Naturkunde, Serie B (Geologie und Paläontologie), 298, 1-159.

Maisch, M. W., \& Reisdorf, A. G. (2006a). Evidence for the longest stratigraphic range of a post-Triassic Ichthyosaur: a Leptonectes tenuirostris from the Pliensbachian (Lower Jurassic) of Switzerland. Geobios, 39, 491-505.

Maisch, M. W., \& Reisdorf, A. G. (2006b). Erratum to the article "Evidence for the longest stratigraphic range of a post-Triassic Ichthyosaur: a Leptonectes tenuirostris from the Pliensbachian (Lower Jurassic) of Switzerland". Geobios, 39, 743-746.

Maisch, M. W., Reisdorf, A. G., Schlatter, R., \& Wetzel, A. (2008). A large skull of Ichthyosaurus (Reptilia: Ichthyosauria) from the Lower Sinemurian (Lower Jurassic) of Frick (NW Switzerland). Swiss Journal of Geosciences, 101, 617-627.

Martill, D. M. (1993). Soupy Substrates: A Medium for the Exceptional Preservation of Ichthyosaurs of the Posidonia Shale (Lower Jurassic) of Germany. Kaupia-Darmstädter Beiträge zur Naturgeschichte, 2, 77-97.

Maubeuge, P. L. (1979). Observations stratigraphiques et tectoniques dans la région de la Staffelegg (Jura d' Argovie), Suisse. Bulletin de la Société belge de géologie, 88, 281-283.

McGowan, C., \& Motani, R. (2003). Encyclopedia of paleoherpetology, Part 8: Ichthyopterygia (p. 173). München: Verlag Dr. Friedrich Pfeil.

Menkveld-Gfeller, U. (1998). Der Fischsaurier vom Teysachaux: Ein echter Freiburger? Schweizer Strahler, 11, 345-347.

Merian, P. (1852). Ueber den Aargauischen Jura. Bericht über die Verhandlungen der Naturforschenden Gesellschaft in Basel, 10, 137-144; Basel.

Meyer, C. A., \& Furrer, H. (1995). Taphonomie und paläoökologische Rekonstruktionen: Beispiele aus dem Mesozoikum des Jura. Eclogae Geologicae Helvetiae, 88, 711-720.

Moesch, C. (1867). Geologische Beschreibung des Aargauer-Jura und der nördlichen Gebiete des Kantons Zürich. Beiträge zur Geologischen Karte der Schweiz, 4. Lieferung, 1-319.

Moesch, C. (1874). Der südliche Aargauer Jura und seine Umgebungen. Beiträge zur Geologischen Karte der Schweiz, 10. Lieferung, 1-53.

Motani, R. (1999). Phylogeny of the Ichthyopterygia. Journal of Vertebrate Paleontology, 19, 473-496.

Mühlberg, F. (1915). Geologische Karte der Schweiz, Erläuterungen zur Geologischen Karte des Hauensteingebietes (WaldenburgOlten) $1: 25,000$ (Spezialkarte Nr. 73) (31 pp.). Bern: A. Francke.

Ohmert, W. (1976). Das Toarcium-Profil von Ballrechten (Oberrheingebiet südlich Freiburg). Jahreshefte des Geologischen Landesamts Baden-Württemberg, 18, 79-103.

Oppel, A. (1856-1858). Die Juraformation Englands, Frankreichs und des südwestlichen Deutschlands, nach ihren einzelnen Gliedern 
eingetheilt und verglichen. Jahreshefte des Vereins für vaterländische Naturkunde in Württemberg, 12, 121-556.

Peyer, B., \& Koechlin, E. (1934). Ein Saurierwirbel aus dem Terrain à chailles von Grellingen (Berner Jura). Verhandlungen der Naturforschenden Gesellschaft in Basel, 45, 68-77.

Pharisat, A., Contini, D., \& Frickert, J.-C. (1993). Early Jurassic (Lower Toarcian) "Ichthyosaurs" from Franche-Compte, France. Revue de Paléobiologie, Volume spécial, 7, 189-198.

Reisdorf, A. (2001). Neue Lias-Profile entlang der Transitgasleitung der TRG 3: Wirbligen (BL) und Titterten (BL). Archäologie und Museum, Berichte aus Archäologie und Kantonsmuseum Baselland, 43, 43-48.

Reisdorf, A. G. (2007). No Joke Movement: Mehr über den Hauensteiner Ichthyosaurier und rezente marine Lungenatmer. Textnoten zur Physiologie, Pathologie und Taphonomie; weiterführende Literatur. Mitteilungen der Naturforschenden Gesellschaft des Kantons Solothurn, 40, 23-49.

Reisdorf, A. G., Wetzel, A., Schlatter, R., \& Jordan, P. (2011). The Staffelegg Formation: a new stratigraphic scheme for the Early Jurassic of northern Switzerland. Swiss Journal of Geosciences, 104, 97-146.

Richter, H. (1987). Die Mikrofauna des unteren Toarciums der Nordschweiz. Neues Jahrbuch für Geologie und Paläontologie, Abhandlungen, 176, 137-155.

Rieber, H. (1973). Fauna und Stratigraphie einer oolithischen Kalkbank aus dem Toarcium von Gipf (Kanton Aargau). Eclogae Geologicae Helvetiae, 66, 657-665.

Riegraf, W. (1986). Stratigraphische Verbreitung der Ammonitengattung Catacoeloceras im Toarcium Europas. Senckenbergiana Lethaea, 67, 305-313.

Schlatter, R. (1982). Zur Grenze Pliensbachian-Toarcian im Klettgau (Kanton Schaffhausen, Schweiz). Eclogae Geologicae Helvetiae, 75, 759-771.

Schlegelmilch, R. (1992). Die Ammoniten des süddeutschen Lias. 2., neubearbeitete und ergänzte Auflage (p. 241). Stuttgart, Jena, New York: Gustav Fischer Verlag.

Schmidt-Effing, R. (1972). Die Dactylioceratidae, eine AmmonitenFamilie des unteren Jura (Systematik, Stratigraphie, Zoogeographie, Phylogenie mit besonderer Berücksichtigung spanischen Materials). Münstersche Forschungen zur Geologie und Paläontologie, 25(26), 1-255.

Schulbert, C. (2001). Die Ammonitenfauna und Stratigraphie der Tongrube Mistelgau bei Bayreuth (Oberfranken). Beihefte zu den Berichten der Naturwissenschaftlichen Gesellschaft Bayreuth e.V., 4, 1-183.
Seilacher, A. (1990). Die Holzmadener Posidonienschiefer: Entstehung der Fossillagerstätte und eines Erdölmuttergesteins. In W. K. Weidert (Ed.), Klassische Fundstellen der Paläontologie, Band 2 (pp. 107-131). Korb: Goldschneck.

Senftleben, G. (1923). Beiträge zur geologischen Erkenntnis der Westlägern und ihrer Umgebung. Ph.D. dissertation, University of Zurich, Zürich, Switzerland, $151 \mathrm{pp}$.

Söll, H. (1965). Der Lias in zwei Schürfbohrungen im Markgräflerland (Südbaden). Jahreshefte des Geologischen Landesamtes Baden-Württemberg, 7, 149-180.

Streif, K. (1981). Bezirksschülerin fand Schädelfragmente eines Fischsauriers. Badener Tagblatt, 24. Juni 1981.

von Buch, L. (1839). Über den Jura in Deutschland (p. 87). Berlin: Druckerei der Königlichen Akademie der Wissenschaften.

von Hillebrandt, A. (1981). Kontinentalverschiebung und die paläozoogeographischen Beziehungen des südamerikanischen Lias. Geologische Rundschau, 70, 570-582.

von Huene, F. (1939). Ein ganzes Ichthyosaurier-Skelett aus den westschweizerischen Voralpen. Mitteilungen der naturforschenden Gesellschaft in Bern, Neue Folge, 1939, 1-14.

von Huene, F. (1948). Short review of the lower tetrapods. In A. Du Toit (Ed.), Robert Broom Commemorative Volume (pp. 65-106). Cape Town: Royal Society of South Africa, Special Publications.

von Jaeger, G. F. (1856). Über eine neue Spezies von Ichthyosauren (Ichthyosaurus longirostris OwEN ET JÄGER) nebst Bemerkungen über die übrigen in der Liasformation Württembergs aufgefundenen Reptilien. Nova acta Academiae Caesareae LeopoldinoCarolinae Germanicae naturae curiosorum, 25, 937-967.

Wetzel, A., \& Allia, V. (2003). Der Opalinuston in der Nordschweiz: Lithologie und Ablagerungsgeschichte. Eclogae Geologicae Helvetiae, 96, 451-469.

Wetzel, A., Allia, V., Gonzales, R., \& Jordan, P. (1993). Sedimentation und Tektonik im Ostjura. Eclogae Geologicae Helvetiae, $86,313-332$.

Wetzel, A., \& Reisdorf, A. G. (2007). Ichnofabrics elucidate the accumulation history of a condensed interval containing a vertically emplaced ichthyosaur skull. SEPM (Society for Sedimentary Geology) Special Publications, 88, 241-251.

Ziegler, M. (1958). Geologische Untersuchungen zwischen der Staffelegg und dem Bözberg (Aargauer Jura). Unpublished Master's thesis, University of Zurich, Zürich, Switzerland.

Ziegler, M. A. (1967). Exkursion Nr. 27 Basel-Frick-StaffeleggAarau-Bremgarten-Zürich. Teilstrecke II. Frick-Staffelegg_Aarau. In R. Trümpy (Ed.), Geologischer Führer der Schweiz, Heft 6 (pp. 470-476). Basel: Wepf \& Co. 